\title{
Making Sense of Leadership Development: Developing a Community of Education Leaders
}

Catherine McCauley-Smith,

Teesside University Business School, Teesside University, Middlesbrough, UK.

Sharon J Williams

Cardiff Business School, Cardiff University, Cardiff, UK.

Anne Clare Gillon

Faculty of Business and Creative Industries, The University of the West of Scotland, Paisley, UK.

Ashley Braganza

Brunel Business School, Brunel University, Uxbridge, UK.

Corresponding author: C. McCauley-Smith, Teesside University, Borough Road, Middlesbrough, TS1 3BA. Email c.mccauley-smith@tees.ac.uk 


\title{
Making Sense of Leadership Development: Developing a Community of Education Leaders
}

\begin{abstract}
In education literature there is a distinct lack of scholarly work on issues of leadership other than on functional leadership at lower levels or high level individual activity which dominates existing studies. This empirical research is based on the result of a merger of education providers within the North East of England which resulted in a new collaborative organisational form. A crucial aspiration of the newly merged organisation was to provide an overarching innovative leadership structure to facilitate integrated leadership. The specific focus of the paper is participants of a bespoke post graduate learning intervention with the aim of understanding how the participants make sense of their learning and their role within the wider context of an integrated leadership structure. The application of sensemaking to empirical studies is under-researched and of particular importance to this study. We identify five key defining sensemaking characteristics which assisted student-leaders in making sense of a leadership development intervention and assisted in developing a community of education leaders. The reflective accounts of the student-leaders indicated a combined approach of distributed, shared and collaborative leadership. Whilst the study was conducted in the UK the concepts and ideas are likely to have international application.
\end{abstract}

Keywords: leadership; postgraduate Higher Education; critical sensemaking; leadership development

\section{Introduction}

This paper investigates leadership development in a newly merged school environment. Improving the leadership of schools was and is currently a matter of considerable concern for politicians, employers and parents everywhere (Department of Education, 2010a). More recently, in the UK, large capital expenditure projects are becoming evident: schools are closing, merging, being rebuilt or new schools are being built. These developments are transforming educational landscapes and communities. A recent report calls for further changes to educational institutions and identifies effective leaders as being crucial to successful change (Department of Education, 2010b). It recognises the need for leadership development to support future leaders, however, the 
focus is on head teachers and principals. Reference is made to wider leadership but this is not specific in relation to roles and functions. There are other studies in the context of school leadership (Harris, 2003; 2008); however, these portray school leadership that stems from functional aspects and more concerned with managing delivery of politically imposed curricula.

Our study moves away from these conventional views of school leadership as 'headship' to a more contemporary model of educational leadership; one which facilitates broader-based leadership below the principal / head and spreads across disciplines within a school. Specifically, our research identifies the sensemaking practices of student-leaders - individuals in leadership positions who want to learn about leadership practices. We are particularly interested in addressing the question: How do student-leaders make sense of their leadership development? Much of the previous research around leadership and sensemaking has focused on leaders in situ. We draw upon the seven characteristics of sensemaking, as defined by Weick (1995), to provide an insight to how this sensemaking process is aligned to a learning and development experience. Specifically the contribution of this paper is the empirical testing of the sensemaking framework within the context of a postgraduate learning and development experience.

Using Mills et al.'s (2010) critical sensemaking approach for analysis we found that five of Weick's (1995) seven distinguishing characteristics are more prominent in enabling student-leaders to better understand leadership in context and help to bring about shared practice: retrospective plausibility, enactment, social identity construction and grounded in identity. Sensemaking is valuable in uncovering the social psychological processes that contribute to organisational outcomes, rather than focusing on the outcomes themselves (Weick, 1995). Also of importance to this study is the further development of each individual's sensemaking when they come together as a group (Maitlis, 2005). For the purposes of our research sensemaking is defined as making sense of own and others' leadership during and post a leadership development learning intervention.

Empirically, our findings are based upon an in-depth study of three schools, in North East England, that were merged into one new school. The new school is situated on a purpose built single learning campus for students aged between two and nineteen years. The new school's executive director identified the role of leadership and leadership development as critical success factors for the School's performance. Cohen 
and Bailey (1997) propose that management philosophy and attitude should enable, promote and stimulate a set of employees who are interdependent and mutually accountable for a common objective.

The remainder of the paper is structured with a review of the leadership and sensemaking literature. The next section details the methodology, case organisation and an outline of the education programme. The results section is followed by a discussion of our research in relation to key themes and the framework of sensemaking. The concluding section outlines the limitation of the study and suggests areas of further research.

\section{Distributed, shared and collaborative leadership}

Traditional organisational forms characterised by hierarchy, division of labour and managerial control (Weber 1978) are changing. They are emerging as new organisational forms in response to the changing nature of external environments. Collaboration has become a necessity along with a need to share resources and information. Hand-in-hand with new organisational forms is the displacement of the dualistic and dyadic nature of relationships between leaders and the led. New organisational forms, in particular those of a collaborative nature imply a sharing of leadership and an espoused sharing of power. This change is enabled and facilitated through empowerment and distribution of previously centrally controlled leadership behaviours. Osborn et al. (2002) argue that leadership is dependent on context particularly when linked with change. The context for our research concerns a purposeful learning intervention designed to encourage leadership cultural change i.e. an integrated leadership structure facilitated through the bringing together of previously disparate leaders.

In spite of decades of leadership research studies, the concept of 'leadership' remains unclear and elusive (Alimo-Metcalfe and Alban-Metcalfe, 2006). Reviews of the major leadership theories over the last 100 years provide a context for current thinking on leadership. The development of leadership theory shown in Table 1 outlines a radical shift over time in the emphasis of the understanding of the nature of leadership (Tamkin et al, 2010, Hunt 2005). 
Bryman (1992) coined the term 'new leadership' for the group of studies focussing on transformational leadership, charisma, and vision. Other contemporary leadership theories, which are focal to our research, include distributed, shared and collaborative leadership.

Distributed leadership is in part a response to the requirement for effective leadership in an increasingly complex, fast-paced, hazardous and unpredictable world (Ancona and Backman, 2010). There is a real need to harness the leadership capabilities of all employees in the organisation for it to perform at its maximum potential. Distributed leadership recognises the employee's need to participate in leadership given the recent significant rise in highly educated and self-motivated employees (Barry, 1991). Bolden's (2011) review of distributed leadership theory and research includes extensive debate about the similarities and differences between the distributed leadership approach and related concepts. Furthermore, the terms shared and distributed leadership are often intertwined. Fitzsimmons et al's (2011) study acknowledges that for the most part distributed leadership (and shared leadership) is only partially understood. Bolden (2011, p. 256) goes on to say that distributed leadership "appears to have been picked up and promoted within UK education policy" and has significantly shaped educational leadership (see also Edwards, 2011). Although distributed leadership is commonly associated with school leadership, the scholarly literature is concerned largely with distributing teachers to lead curricula and not leadership per se. As highlighted in Connolly et al.'s (2000) study on leadership in educational change, the role of leadership is new to head teachers. Again, their study deals with the functional aspects of management rather than leadership. Other studies denote distributed leadership in schools as instructional, formal and aligned to teacher practice (Camburn et al. 2003; Harris, 2004; Spillane, 2005; Harris and Spillane, 2008)

Shared leadership includes definitions ranging from lateral leadership relationships, an expanded role for followers and leadership behaviour that induces others to take action towards a common goal (Pearce and Conger, 2007). Others define it as a process where leadership is carried out by a team as a whole rather than by a single individual and where knowledge is provided through a collective (Ensley et al, 2006). Shared leadership has been described as a positive enabler for improved organisational performance. It encourages behaviours such as active engagement and problem solving (Ensley et al., 2006). Intergroup leadership is also central to the integration of groups, otherwise leaders may find bringing together disparate groups 
problematic (Pittinksy and Simon, 2007). Marion and Uhl-Bien (2001) propose that transformational leadership promotes subservient follower behaviour set to achieve goals beyond individuals' expectations. It is important for leaders to accurately perceive the network relations that connect people, to actively manage those relations (Balkundi and Kilduff, 2005). An important part of being a leader is to understand how you are perceived by others (Pomeroy, 2005).

Collaborative leadership includes assembling the right teams (Greiner, 1972), bringing leaders together so that they work collaboratively with colleagues inside the organisation. There is a need to provide guidelines for senior managers who work via 'coalitions, alliances and partnership' (Archer and Cameron, 2009, p.232). Collaborative leadership requires shared control, joint endeavour and engaging in mutual dialogue to problem solve (Raelin, 2004). Team members use mutual dialogue to identify new ways to deal with problems and collectively make sense so to overcome obstacles and move forward together. Interest in this particular model is gaining momentum, also referred to as collective leadership. Collaborative leadership does not depend on any one member but does depend on everyone participating (Raelin, 2006).

\section{Leadership development: setting up a learning system}

Gold et al., (2010) argue that there is a need to demonstrate the investments made in costly development activities are appropriate, provide real value, and contribute to organisational performance improvements. Leskiw and Singh (2007) show that organisations see leadership development as an increasingly critical and strategic imperative. Organisations that invest in developing leaders to prepare for the future will be better placed to meet forthcoming challenges (Fulmer, 1997). Research supports the link between the investment in leadership development and the resulting positive impact on business performance. In a report produced for the UK Institute for Employment Studies, Tamkin et al., (2008, p. 64) recommended that in order to improve measures, such as profit per employee and productivity per employee, companies should focus on 'long term development, especially of managers'. A CIPD survey reported one of the most effective employee retention strategies was to invest in the people management skills of leaders and managers (CIPD, 2010). Hernez-Broome and Hughes (2004) identify a need for leadership skills at many levels in organisations especially in light of an ongoing drive to flatten organisational structures. Traditionally leadership development has been focussed on individual, primarily intrapersonal, skills and 
abilities (Barling et al., 1996), Day (2000) classifies this as leader development. Leadership can be considered as a complex interaction between the leader and the social and organisational environment (Fielder, 2006). The focus for leadership development in contrast is on social capital, centred on a relational leadership model with an emphasis on the development of social awareness and skills (Day, 2000; Iles and Preece, 2006). Smeby (2007) discusses how professional education has moved from a 'vocational model to an academic model' (p. 207) that blends knowledge, skills and reflection.

One of the key aspects of Human Resource Development (HRD) has been the implementation of HRD interventions to improve performance and recently there has been a move from Management Development (MD) towards Leadership Development (LD) (Leskiw and Singh 2007). This coupled with a debate on the variances between leader development as opposed to leadership development signifies that both are necessary to creating and sustaining leadership for successful organisations (Day, 2000, Illes and Preece 2006; Dalakoura; 2010). This makes development of the individual leader and how they interact with other leaders all the more significant. The key here is openness to encourage sharing and integration of leadership practice in order to gain a sense of others and the environment. This brings about a step change from being a leader to engaging with leadership (Day, 2000); hence our definition of sensemaking provided earlier The unsettling and untying of old practice and engaging with new practice leads to periods of uncertainty and 'actors often struggle with changing roles, processes and relationships' (Luscher and Lewis, 2008 p 222). Ensuing ambiguities are likely to follow concerning the roles of the different organisations, the 'need to pursue integration' (Vaara, 2003 p. 860) and human resource related problems not being given sufficient attention (Greenwood et al., 1994).

\section{Sensemaking}

Weick et al. (2005) discuss the process of sensemaking and analyse how people think about things and what things mean to them. Sensemaking can be described as the retrospective process that is used to reduce ambiguity and to address uncertainty (Weick, 1995). Weick (2001) explains how we aim to make sense of ambiguity through a continuous process of improvisation. The seven characteristics in the sensemaking framework (see table 2) are defined as: identity construction; retrospective; enactment; social; ongoing; focused on and by extracted cues and plausibility (Weick, 1995, p. 17). 
This framework offers an explanation for how individuals and organizations make sense of their environment. Although it is unrealistic for any one study to illustrate all characteristics, this framework is useful in providing a guide for inquiry into sensemaking by suggesting "what sensemaking is, how it works and where it can fail" (Weick, 1995, p.18). Sensemaking makes the unintelligible intelligible so that people can interpret and contextualize events on their terms.

The 'trigger' for sensemaking is often chaos or perceived contradictions, what Weick (2001, p 10) describes as 'discrepancies, surprise, the unexpected, the dissonant, are implied as the occasion that stirs thought'. When dealing with chaos or contradictions individuals look to rationalise events and establish some form of explanation so they can return to what they were doing before the disruption. If it is not possible to return to previous events then a new response or action follows based on the interpretation - in effect, learning (Daft and Weick, 1984, p. 286). Feedback from learning in turn provides new data for interpretation or reinterpretation. The leadership learning intervention adopted a problem-based learning approach and was designed to challenge existing perceptions of leadership.

\section{Insert table 2 about here}

Organisational transformational change poses daunting challenges and middle managers charged with communicating and implementing change often struggle for meaning (Luscher and Lewis, 2008). Organisational sensemaking is fundamentally a social process through which people interpret their environment in and through interactions with others and thus construct stories that allow them to understand their new world and to act collectively (Isabella, 1990; Sackman, 1991, Weick and Roberts, 1993). Notably Weick and Roberts' (1933) study coined the phrase of the 'collective mind' dependent upon how people interrelate.

We use Weick's (1995) sensemaking characteristics framework to examine how student-leaders in a new school structure make sense of their leadership development experience. Next, we present the methods used to gather and analyse the empirical evidence.

\section{Methodology}

This case study research focuses on a group of student-leaders who were promoted to leadership positions in a School created by merging three schools and how they make sense of leadership. Case study research is acknowledged as a methodology and strategy of inquiry (Creswell, 2007; 
Denzin and Lincoln, 2005; Eisenhardt, 1989; Yin, 2003). It facilitates 'exploration of a bounded system through detailed, in depth data collection involving multiple sources of information and reports a case description and case based themes' (Creswell, 2007 p. 73). We acknowledge the concerns in the literature about single case study research however we counteract this in some way by this research being longitudinal and by providing detailed accounts by student-leaders from across their programme of study. We also acknowledge that we draw from a small sample however we note that published studies about students range from 1 to less than 20 participants as well as larger studies of 500 or more participants. Our research sits in the middle of the first range and by focussing on a purposeful sample of a particular layer of leadership in which all members took part i.e. nine senior level student-leaders, we were able to interview those who would be in the best position to help us answer the research question (Miles and Huberman, 1994).

The concept of 'sensemaking' is a useful theoretical approach to explore how learners make sense of their identities (self and others) and their environments (Weick 1995). We adopted Mills et al.'s (2010) critical sensemaking as it provides the means to trace how practices become acceptable. Both sensemaking and critical sensemaking are not widely recognised as a method of analysis (Mills et al., 2010), however, there have been some use of sensemaking as a heuristic for understanding the processes that led to the various outcomes (e.g. O'Connell and Mills, 2003; Mills et al., 2006). We use sensemaking to establish how student-leaders make sense of their leadership development.

\section{Learning intervention context and research process}

An offer to participate in a post graduate learning intervention was made to the newly formed school's Wider Leadership Team. This was accepted by all nine members who successfully completed their studies. These nine-student-leaders are our unit of analysis and are made up of six females and three males, of which eight were qualified teachers and one senior member of the support staff. While all have several years work experience, most have relatively little leadership experience other than leading aspects of the curricula. The roles include eight progress leaders (equivalent to assistant head teacher) and a Head of IT Systems.

Semi-structured retrospective interviews were conducted with the nine postgraduate student-leaders at different stages of their learning intervention. Schutz (1967) and Weick (1995) argue that people make sense by looking back on events and this retrospective analysis helps with their understanding. The method used is consistent with other studies of students' perceptions of learning (Martin and Booth, 1997; Cassell 
and Symon, 2004; Kempster, 2009). The nine-student-leader cohort forms a whole leadership layer within the organisation and all confirmed agreement to be interviewed. The duration of interviews ranged from one to two hours. To provide anonymity student-leaders are referred to as student-leader A through to I. Ethics approval and informed consent were obtained prior to the research.

\section{Data and analysis}

Audio-taped recordings and fully transcribed interviews provided a rich set of data. The method used to analyse the interview transcripts was applied critical sensemaking (Mills et al., 2010) as it provides the means to trace how practices become acceptable. This analytical approach supported a contextual constructivist stance, i.e. one in which interviewees' views were investigated to find out about how they made sense of things within their environment. By combining King's (1998) work with critical sensemaking the authors constructed a template of a priori codes to represent Weick's sensemaking characteristics framework. In qualitative template analysis an initial template is constructed in order to be able to analyse text through a process of coding. The construction of the initial template is based upon two key signposts; the first is the research topic i.e. the literature, and the second is the themes that emerge from reading the first few transcripts. The initial template is then built upon as the analysis progresses. The initial template reflects a hierarchical structure of a priori codes which are then subdivided into lower order codes. Once the key themes were identified the order was decided post analysis.

Out of the three most common approaches to presentation is an account derived from the main case based themes (King, 1998; Weick et al. 2005; Creswell, 2007; LipsWierma and Douglas, 2007; Nadin and Cassell, 2007; Mills et al. 2010) and for which illustrative examples are highlighted through the use of direct quotes from the studentleaders.

\section{The Case Study}

The New School is a merger of three schools premised on the formation of a Federated Governing Body to allow a single, focussed approach to governance and a collaborative approach to education delivery. Under the terms of the 2002 Education Act, a federation is a group of two or more maintained schools (primary, secondary and/or special schools) with a joint governing body. They can operate with a school home base 
but co-share resources. 'Hard edged' federation takes the grouping a step further and includes 'close collaboration' between schools in a variety of circumstances who formally agree to work together to raise standards.

The three schools were very different in nature, composition, design and purpose comprising a large secondary community school and specialist Arts College, a special school and technology college that catered for the full range of pupils with special educational needs across a wide ability range and a small primary school. The merged school was the first education establishment in the UK that combined the resources of three schools on one site, creating a prototype learning environment that would bring together primary, secondary and Special Educational Needs provision.

The merger is a novel development in that the three schools are lead by one overarching leadership structure and managed with one joint budget (i.e. a hard edged and close collaboration unlike other mergers of schools that share a site but not necessarily core resources such as human resources and finances). At the heart of this merger is workforce reform, integration and collaboration - a shift away from a hierarchical, traditional leadership model. The context of the merger extends leadership development for key leaders with devolved responsibilities across the three schools. The merged leadership structure comprises of three hierarchical layers: an Executive Director, an Executive Leadership Team and a Wider Leadership Team. The first step was putting the right people in the right place (O'Reilly et al., 2010; Connelly et al., 2000; Mumford et al., 2000a and b). The second step was deploying a Human Resource Development strategy with a postgraduate programme of study at its pinnacle. The Executive Leadership Team identified key investments in the Wider Leadership Team in order to develop individuals as leaders and collaborative, shared leadership praxis. The views of the Executive Leadership Team indicated a clear demand for a specialist learning intervention focusing on leading and managing change. Consultation about programme design was completed within fourteen months post merger with the studentleaders able to commence their studies two months later.

The detailed design of the learning intervention is beyond the scope of this paper. However, the overall learning philosophy is problem-based learning designed to promote students' self-confrontation, challenging of others, and acceptance of critique. Providing opportunities to rehearse critical thinking within the discipline of leadership and change was considered as important (Hussain et al., 2007). The rationale for the learning intervention was to develop leadership knowledge, foster collaboration and 
integrate the organisation. It was designed very much with the workplace in mind and specifically to facilitate critical thinking and debate through the leverage of curricula and use of classrooms as forums (Kezar et al., 2011). The course ran for two years and sessions were structured to facilitate conversation, shared action, and shared reflection. Scharmer (2001) refers to a term of forming new will, which leads to new practices. Reflective practice typically concerns critical inquiry and managers learning from their own organisational context to bridge the theory/practice divide. Critical inquiry combined with mutual dialogue creates openness that will secure a high rate of commitment to organisational goals (Raelin, 2006).

\section{Analysis and results}

The student-leader cohort was brought together to form a new school's leadership team that required them to join together, to integrate, to collaborate and share leadership. Consequently, they had to make sense of their identity, learning and position within the new structure (Reid et al. 2008; Marshall and Case, 2010). Reid et al. (2008) elaborate the importance of cross cultural communication. We can relate this to the merger of three different schools. There is a need to emphasize an 'established set of core values as a basis for the ability to deal with ambiguity and uncertainty, the ability to build networks and to develop social networks.

Hallett's (2010) study mirrors our research as it represents postgraduate students who are qualified teachers, in their case within a particular academic discipline. Hallett focused on student support advocating critical thinking and 'reflective, analytical debates that allow opportunities to express a viewpoint, and critique the viewpoints of others' (p. 231). The post graduate students in our case included teachers and nonteachers studying a course that offered similar pedogical structures. We refer to our students as student-leaders- not because they lead students but because they themselves are newly appointed leaders undertaking leadership studies. Weick's seven defining characteristics of sensemaking and Mills et al's interpretations (see Table 2) provided a template of apriori codes for the data analysis:

\section{A priori code 1: Retrospective plausibility}

Sensemaking is retrospective, ongoing and a comparative process. To interpret the present we rely on past events to give meaning and make sense of a situation (Weick, 1995). When doing so we extract certain cues which encourage us to focus on certain 
events and ignore others. These decisions are driven by plausibility rather than accuracy and are influenced by cues that make our perceptions plausible. Similarly, the environment in which we are making sense of events can constrain or create sensemaking, as can the interaction with others thus reducing barriers to connecting up to integrated leadership.

Sensemaking is a comparative process and past events and behaviours are employed to provide meaning and sense to new situations (Weick, 1995). Some student-leaders articulated quite dramatic changes in their leadership style when recollecting thoughts about their earlier leadership behaviours (i.e. employing the past to make sense of the present). Student-leader A described herself as a "horrendous micro manager" before attending the course. However, by the end of the intervention, some two years later, she described herself as able:

"to give the team the quality [leadership] that they need in terms of getting on with the job..... rather than me wanting to do everything".

Student-leader $\mathrm{C}$ recognised there were different situations that required her to take a different approach to leadership. Student-leader G spoke of using the models of leadership that had been presented to him during the two year course to bring about change.

When making sense of their behaviour since completing the leadership programme, several student-leaders mentioned calmness and objectivity. Student-leader C spoke about being calmer in meetings and the ability to be more objective. Similarly, Student-leader B reflected as being:

"definitely more calm and think about how to communicate whatever message I am trying to get across especially to the senior leadership team”.

Another student-leader clearly indicates how she developed over a two year period to become calmer and more in control of her emotions by reflecting that:

“my approach ... has been very different...I don't think it's as hot headed ... but it is still getting the results that I desire" [Student-leader B].

One student-leader described how the programme has helped her to become more organised:

I'm more prepared, much more prepared and I know how much preparation I need to do... [Student-leader D].

Another student-leader spoke of being more patient and being more willing to listen: 
"I tend not to jump in so quickly....take a step back or think about things first.

I think also it is important to listen to others ..." [Student-leader I].

The student-leaders identified and articulated the softer skills that had been developed as a result of the programme. Confidence featured in all accounts with many referring to their ability to voice opinions and challenge proposals. Increased self esteem and assurance were other shared reflections. For Student-leader [I] it was the selfrealisation that her contribution was valued and she was better at her job than she had led herself to believe prior to the programme.

"Before the course I was really quite under-confident and didn't think I was taken seriously sometimes but that has changed now.....I stand up for myself much more now and am much more assertive when talking to the senior leadership team. I know a lot more about leadership and change stuff now..."

Other comments included:

"I am now more confident and more self assured to actually voice my opinion rather than just get on with it and be a manager as opposed to a leader so it's made me more confident in that aspect." [Student-leader A].

“.... we don't accept necessarily everything ..... so we're now willing to speak up and say 'have you ever thought about doing it this way' which I think can only be good" [Student-leader E].

\section{A priori code 2: Enactment of the environment and plausibility}

Several student-leaders noted the importance of having time with fellow colleagues in developing a sense of community. For example Student-leader E stated:

"I think that even just having that time to spend talking to each other, listening to each other ... you know seeking each others' views, understanding how things work you know among different colleagues that's really helped you know that sense of community."

Student-leader B highlighted the importance of influence in enacting the environment by stating:

"By knowing and understanding more about leadership and change the more you can persuade others [throughout the organisation] because you kinda know what you are talking about".

Plausability and sensemaking relates to continually redrafting an emerging story; in our case a new leadership structure. Through processes of deconstructing and 
reconstructing leadership stories within peer sensemaking sessions the student-leaders were able to work together to develop their understanding and knowledge about each other. Furthermore by reflecting on their educational intervention some student-leaders recognised their ability to more effectively shape team dynamics and create a different work environment. 'Theoretical cues' manifested as theories such as style, understanding and knowledge of leadership and a heightened awareness of theoretical underpinning were drawn upon by several student-leaders. The value of having the underpinning leadership theory to help them shape their own behaviour and actions, those of their fellow leaders and how they might influence other members of their team was evident. For example, student-leader B commented:

"It has helped me to understand that there is more than one style and about the importance of recognizing the different styles that play out in our leadership networks."

A similar account was given by Student-leader E who stated:

“...because I'm more aware of the processes that go on behind it, the theories behind what I am doing so I'm able to take those and apply them to what I'm doing and I think being more organised..."

These theoretical cues are being cascaded to subsequent employee levels. For example student-leader $\mathrm{G}$ actively employs his learning to bring about change by talking with his team and collecting information before he suggests any changes. To make sense of their leadership roles and knowledge it would seem that some students have shifted their focus to theoretical cues provided in the course curricula.

\section{A priori code 2 Sub code 1: Driven by plausibility}

Student-leader G indicated that his opinion is credited and valued to a greater extent by senior management having completed the qualification.

The data provided evidence of the leader-students having greater clarification over their contribution and role within the organisation.

"I have always had a close relationship with my pupils and have their respect but now I have this from others too. I feel that I am listened to much more by the senior leadership team and by my colleagues." [Student-leader I] 
Several student-leaders spoke of their ability and confidence to converse with senior colleagues. For example, student-leader I commented she was more confident about putting forward her views and more assertive when talking to the senior leadership team. Similarly, student-leader B recalled:

"[I] think about how to communicate whatever message I am trying to get across especially to the senior leadership team".

\section{A priori code 3: Social interaction}

Sensemaking is social activity which can be provoked by unusual circumstances (Weick, 1995) and transformation change provides a challenging setting. A merger is likely to create a rich source of discourse concerning changes post-merger when 'such changes are likely to become significant 'integration issues' for previously separate organisations....or particular groups of people (Vaara, 2003 p. 863).

All of the student-leaders commented on social interactivity and, in particular, about the sense of community that had developed among the cohort. McMillan and Chavis (1986) defined a sense of community identity as consisting of four components: (1) membership or a feeling of belonging, (2) bi-directional influence from the individual to the group and from the group to the individual, (3) fulfilment of needs, and (4) shared emotional connection. The data analysis revealed that these four components were evident among the group. The feeling of belonging for student-leader A was the solidarity that had developed between the group during the course and how this has transferred to regular meetings. Others mentioned the group as being a support network where problem sharing and solving were key elements of their discussions. Perhaps the most valued element of the community that had developed was the ability to spend time together and

“..have a much a better understanding of what the other [Wider Leadership Team I members do and the problems they have" (Student-leader B).

This wider understanding of the Wider Leadership Team indicates that student-leaders not only act as leaders and deliverers of the curricula, but their collaborative working helps to support the integration of team and the new organisational structure.

Several of the students valued the interaction among members and that all members of the cohort being on the same leadership level offered congruence and enhanced team work. For example, Student-leader [F] reported: 
"I think the experience of going through together as a group of middle leaders has worked really well. ... should help us to work better as a team ... but certainly the experience of going through the [learning intervention] ... was good in terms of creating bonds between the leaders that operate at that level."

The importance of bonding was evident through all of the interviews, Student-leader D felt strongly about the value of a heightened sense of each other:

"You sort of function as a tighter unit because you have that understanding of each other and where, ... you sort of get under the skin of each other in a way that develops bonds and relationships..."

Most of the students acknowledged how they had developed from a group of individuals who did not know each other prior to the course to a mutually supportive group with enduring relationships and strong bonds. These relationships and bonds had developed over the two year course and were being sustained post graduation by all of the studentleaders. This behaviour was endorsed by the Executive Director:

In terms of their knowledge and having teased out all the different elements of leadership I think that's led them to exercise their skills as leaders more consciously and therefore more effectively......some have grown enormously in confidence particularly in terms of their relationships with others.

\section{A priori code 4: Grounded in Identity}

The characteristic of identity construction refers to how our identity is continually shaped by social interaction and experiences (Weick, 1995). Mills et al. (2010, p. 185) explain this as "making sense of the sense maker." The stakes in sensemaking are high when issues of identity are involved, "When people face unsettling differences, that difference often translates into questions such as who are we, what are we doing, what matters and why does it matter". This is coupled with a sensemaking recipe of "how can I know who we are becoming until I see what they say and do with our actions" (Weick et al., 2005, p.416). The fact that all the student-leaders had shared their learning experience and knowledge provided a common platform which they all understood:

“...this marriage of theory and practice I guess we all share that underpinning theory now that should help us to work better as a team" student-leader [F]. 
The majority of the student-leaders were able to provide coherent accounts of how the learning intervention contributed to their role within the organisation. Student-leader A referred to her expansive roles within and across the merged schools. She acknowledged the course facilitated communications wherein notions, leadership theories and language were discussed which she felt enabled credibility and respect among the cohort:

"The MSc opened up conversations and discussions with peers and really helped to understand how things [theories] work....we were connecting and trusting each other."

For some student-leaders the course was not just about self awareness but clarifying the role of and fit with others in the organisation. For example, Student-leader $\mathrm{H}$ felt he had managed to develop a better fit with the organisation. Student-leader B reported a greater awareness of others' roles and the part they played in the building of the [organisational] culture. She linked this to having a "kind of understanding about each other", or what Scharmer (2001) might term a 'common will'. This enabled her to form a definition of leadership and develop a closer fit with the organisation and her colleagues to revise their definition of a particular label (i.e. what it means to be a leader) as a coping strategy, seeking out interactions and rhetorical resources to support redefinition. In most cases, such post course redefinitions sought to develop leadership from a set of private, supervisory, one-on-one activities to a notion of leadership as a higher level of engagement formed through connectivity.

\section{Discussion}

Sensemaking is often associated with how to deal with uncertainty and enacted when the current state is perceived to be different from the expected state (Weick et al., 2005). So often, sensemaking is activated by the question what is different or the same? This paper builds upon and contributes to the work of Weick (1995) and Mills et al (2010) by empirically testing the seven defining characteristics framework of sensemaking within

a leadership development intervention. A priori 1: Retrospective plausibility - A combination of the design of the learning intervention, self reflection and participating in this research has encouraged student-leaders to retrospectively make sense of their leadership development experience and leadership roles. They have been able to develop a wider perspective and understanding of a range of situations. These include 
discussions in leadership forums, the possible tensions, how to address and avoid these when necessary and ability to reflect on their own practices.

A priori code 2: Enactment of the Environment and plausibility - was less prominent from the analysis but nevertheless important as student -leaders clearly recognised the context and content of the learning intervention as an experience that has changed and shaped their views on leadership over their two years of study. They valued the time in which to meet and discuss issues with fellow colleagues, but no one noted examples of how the existing environment might constrain their learning or sensemaking opportunities. We assert that the opposite applies when a bespoke leadership development programme is designed to facilitate challenges to prevailing leadership culture. How the student-leaders enacted their environment was a characteristic that provided significant insights into how the student-leaders were able to transfer knowledge through integration (Ensley et al., 2006). Some student-leaders recognised they affect the environment by the decisions and actions they take as leaders and how they were able to cascade their knowledge to others across the new leadership structure.

A priori code 3 - Social interaction played an important part of the learning process and making sense of the leadership roles and this has been ongoing since the completion of the learning intervention. By focussing on and extracting cues, or what Weick (1995, p 50) refers to as "familiar structures that are seeds from which people develop a larger sense of what may be occurring," can be linked to the theoretical content of the learning intervention. Student-leaders appear to take cues from their learning of leadership theory and how this relates to the 'doing' of leadership. Some student-leaders made positive reference to being different in the way that they work, their approaches to problem solving, their relationships with their colleagues and how they influence others (Raelin, 2004). The accounts provide evidence of being taken more seriously as leaders outside of their functional role by organisational layers above and below them as well as by their peers (Pomeroy, 2005).

A priori code 4 - the student-leaders emerged from the course with a sound grounded identity. We prioritised this code last based on a premise that the template has a logical order with each code intrinsically linked to each other in an algorithmic flow from retrospective recollections to make sense of and qualify their plausibility in terms of 
how they are now considered as credible leaders by each other and by others across the organisation. Furthermore the student-leaders formed strong bonds and have a sense of belonging to a new leadership community.

The Reid study (2008) has particular resonance with our research in that students develop a sense of identity throughout their studies related to their membership of professional groups - we contextualized this as a newly formed leadership community and how the student-leaders established themselves within their new leadership roles and an integrated community is a prominent feature of the results. The student-leaders referred to shaping and legitimising their identity within their new organisation or what Mills et al (2010) refer to as 'making sense of the sensemaker'. Rather than studying leaders in situ we researched leaders within the context of a leadership development learning intervention. We postulate that the students' transition as graduates to members of a leadership community is influenced by the way the students make sense of their learning and how the learning intervention aids collaboration, connectedness and joining up of the organisation (Isabella, 1990; Sackman, 1991, Weick and Roberts, 1993). The student-leaders have become aware of the wider roles within their school and this has helped the Wider Leadership Team become more coherent and effective as a team suggesting a positive link between effective leadership and school leadership (Currie et al, 2005). By engaging in mutual dialogue within their learning system (Leskiw and Singh, 2007) the students were able to express their viewpoints and critique others' and by doing so were able to reduce ambiguities concerned with pursuing integration and move forward together and commit to the new leadership structure (Vaara, 2003). It has certainly strengthened the links between them and other members of staff and as a result is impacting the dynamics (Maitlis, 2005; Luscher and Lewis, 2008) and development of a positive, integrative leadership ethos across the school (Day, 2000; Illes and Preece, 2006; Dalakura, 2010), a new emerging common will is evident (Scharmer, 2001).

\section{Conclusions}

We reported on empirical data collected to make sense of the individual and collective (group) experiences of this cohort of student-leaders. Five of Weick's characteristics were identified as significant in the student-leaders' sensemaking of the learning intervention. Unlike many other studies we have examined sensemaking opportunities 
experienced by student-leaders rather than leaders in situ. These reflective accounts indicate a combined approach of distributed and collaborative leadership has been employed by the student-leaders. We agree with Pye's (2005, p47) sentiments "sensemaking opens up the area of leadership research and analysis." Our analysis of the sensemaking characteristics framework indicates the leadership behaviours go beyond the 'distributed expert' often associated with the teaching profession, to a more collaborative approach evidenced by the student-leaders.

By considering how to develop a community of education leaders we have started to investigate the importance of creating an environment and designing an intervention that is conducive to sensemaking in particular social interactivity and learning and development forums. The learning intervention described here presents further research opportunities that should focus on other sensemaking opportunities with existing or future cohorts of students. Particularly, in revisiting the participants of this study to examine how theory has been embedded in practice in terms of building leadership communities (Edwards, 2001), and explore if hybrid theories in practice emerge over time (Bolden, 2011; Fitzsimmons et al, 2011) through an increased "sense of what might be occurring" (Weick, 1995, p.50). 


\section{References}

Alimo-Metcalfe, B. and J. Alban-Metcalfe, 2006, More (good) leaders for the public sector, Journal of Public Sector Management 91: 203-315.

Ancona, D. and E. Backman, 2010, Distributed leadership: going from pyramids to networks, Leadership Excellence, 27: 11-12.

Archer, D. and A. Cameron, 2009, Tough times call for collaborative leaders, Industrial and Commercial Training, 41: 232-237.

Balkundi, P. and M. Kilduff, 2005. The ties that lead: A social network approach to leadership, Leadership Quarterly, 16: 941-961.

Barling, J., T.Weber and E.K. Kelloway, 1996. Effects of Transformational Leadership training on attitudinal and financial outcomes, Journal of Applied Psychology, 81: 827832.

Barry, D. 1991, Managing the bossless team: lessons in distributed leadership, Organizational Dynamics, 20: 31-47.

Bolden, R. 2011. Distributed Leadership in Organizations: A review of Theory and Research, International Journal of Management Reviews, 13: 251-269.

Bryman, A. 1992. Charisma and leadership in Organizations. London: Sage. In Hunt, J. G., and M. F. Peterson. 1997. Two scholar's views of some nooks and crannies in cross-cultural leadership. The Leadership Quarterly, 8: 343-354.

Camburn, E., B. Rowan, and Taylor, J. 2003. Distributed Leadership in Schools: The Cae of Elementary Schools adopting comprehensive School Reform Models, Education Evaluation and Policy Analysis, 25: 347-373.

Cassell, C. and G. Symon, Eds. 2004. Essential guide to qualitative methods in organizational research. Sage Publications (London).

CIPD 2010. 'Annual survey report 2010: resourcing and talent planning', CIPD.

Cohen, S. G. and G. E. Bailey. 1997. What makes teams work? Group effectiveness from the shop floor to the executive suite. Journal of Management, 23: 239-290.

Connolly, M., Connolly, U. and James, C. 2000. Leadership in Educational change.

British Journal of Management, 11: 61-70.

Connelly, M. S., J. A. Gilbert, S. J. Zaccaro, V. K. Threlfall, M. A. Marks, M. D. Mumford. 2000, Exploring the relationship of leadership skills and knowledge to leader performance. Leadership Quarterly, 11: 65-86.

Creswell, J. W. 2007. Qualitative Inquiry \& Research Design choosing among five approaches (2 ${ }^{\text {nd }}$ Ed.). Sage Publications (London). 
Currie, G., I Boyett, and O. Suhomlinova. 2005. Transformational leadership within secondary schools in England. Panacea for organisational ills? Public Administration, 83: 265-296.

Daft, R. L. and K. E. Weick 1984. Toward a Model of Organisations as Interpretation Systems, Academy of Management Review, 9: 284-295.

Dalakoura, A. 2010. Differentiating leader and leadership development: A collective framework for leadership development, Journal of Management Development, 29: 432441.

Day, D. 2000. Leadership development: a review in context, Leadership Quarterly, 11: 581-613.

Denzin, N. K., and Y. S. Lincoln, 2005. Handbook of qualitative research ( $2^{\text {nd }}$ Ed.). Sage (Thousand Oaks, CA).

Department of Education 2010a. The importance of teaching - The schools white paper 2010, Department of Education (London).

Department of Education 2010b. The case for change, Department of Education (London).

The Education Act 2002. Statutory Instruments 2005 No. 2570 (C.107). Education (London).

Edwards, G. 2011. Concepts of Community: A Framework for Contextualising Distributed Leadership. International Journal of Management Reviews, 13: 301-312.

Eisenhardt, K. 1989. Building Theories from Case Study Research. Academy of Management Review, 14: 532-550.

Ensley, M. D. Hmeileski, K. M. and Pearce C. L. 2006. The importance of vertical and shared leadership within new venture top management teams: implications for the performance of startups. The Leadership Quarterly, 17: 217-231.

Fielder, F. 2006. Research on leadership selection and training, Administrative Science Quarterly, 41: 241-250.

Fitzsimons, D., J. K Turnbull and D. Denyer, 2011. Alternative Approaches for Studying Shared and Distributed Leadership. International Journal of Management Reviews, 13: 313-328.

Fulmer, R. 1997. The evolving paradigm of leadership development, Organizational Dynamics, 25: 59-72.

Gold, J., R. Thorpe, and A., Mumford, 2010. Leadership and Management Development, CIPD. 
Greenwood, R., C.R. Hinings, and J. Brown, 1994. Merging professional service firms. Organization Science, 5: 239-257.

Greiner, L.R. 1972. Evolution and revolution as organisations grow, Harvard Business Review, July-August: 37-46.

Hallett, F. 2010. The postgraduate experience of study support: a phenomenographic analysis, Studies in Higher Education, 35: 225-238.

Harris, A. 2003. Teacher Leadership and school improvement, in Harris, A., Day, M., Hopkins, M., Hadfield, A. Hargreaves and Chapman, C. (eds), Effective Leadership for School Improvement. Routledge (London).

Harris, A. 2004. Distributed Leadership and School Improvement leading or misleading. Education Management Administration and Leadership. 32: 11-24.

Harris, A. 2008. Distributed Leadership: According to the evidence, Journal of Educational Administration, 46: 172-88.

Harris, A. and Spillane, J. P. 2008. Distributed leadership through the looking glass. British Educational Leadership, Management \& Administration Society (BELMAS), 22: 31-34.

Hernez-Broome, G. and R.L. Hughes, 2004. Leadership development: past, present and Future, Human Resource Planning, 27: 24-32.

Hunt, J. G. 2005. Explosion of the Leadership Field and LQ's changing of the Editorial Guard. The Leadership Quarterly, 16: 1-8.

Hussain, R.M.R., W.H.W., Mamat, N., Salleh, R.M. Saat, and T. Harland, 2007. Problem based-learning in Asian universities, Studies in Higher Education, 32: 761772.

Iles, P. and D. Preece. 2006. Developing leaders or developing leadership? The Academy of Chief Executives Programmes in the North East of England, Leadership, 2: 317-340.

Isabella, L. A. 1990. Evolving interpretations as a change unfolds: How managers construe key organizational events. Academy of Management Journal, 33: 7-41.

Kempster, S. 2009. How Managers have Learnt to Lead: Exploring the Development of Leadership Practice. Palgrave MacMillan (Basingstoke).

Kezar, A., T.B. Gallant, and J. Lester, 2011. Every day people making a difference on college campuses: the tempered grassroots leadership tactics of faculty and staff, Studies in Higher Education, 36: 129-151.

King, N. 1998. Template Analysis in Symon, G and Cassell, C. Eds, 1998. Qualitative Methods and Analysis in Organizational Research, Sage Publications (London). 
Leskiw, S. and P. Singh, 2007. Leadership development: learning from best practices. Leadership and Organisation Development Journal. 28: 444-464.

Lips-Wiersma, M. and D, T. Hall, 2007. Organizational career development is not dead; a case study on managing the new career during organizational change. Journal of Organisational Behaviour, 28: 771-792.

Luscher, L.S. and M.W. Lewis. 2008. Organizational Change and Managerial Sensemaking: Working through paradox. Academy of Management Journal, 51: 221240.

Maitlis, S. 2005. The Social Processes of Organizational Sensemaking. Academy of Management Journal, 48: 21-49.

Marion, R. and M. Uhl-Bien. 2001. Leadership in complex organisations. The Leadership Quarterly, 12: 389-418.

Marshall, D. and J. Case, 2010. Rethinking 'disdvantage' in higher education: a paradigmatic case study using narrative analysis. Studies in Higher Education, 35: 491504.

Martin, F, and S. Booth, 1997. Learning and Awareness. Erlbaum Associates (New Jersy).

McMillan, D.W. and D.M. Chavis, 1986. Sense of community: A definition and theory. Journal of Community Psychology, 14, no. 1: 6-23.

Miles, M.B. and A.M. Huberman, 1994. Qualitative Data Analysis: An Expanded Source Book. Sage (London).

Mills, J.H, A. Thurlow, and A.J. Mills, 2010. Making sense of sensemaking: the critical sensemaking approach. Qualitative Research in Organisations and Management: An International Journal, 5: 182-195.

Mills, J.H. T.G. Weatherbee, and Colwell, S.C. 2006. Ethnostatistics and sensemaking: making sense of business school rankings, Organizational Research Methods, 9: 1-25.

Mumford, M.D., S.J. Zaccaro, M.S. Connelly, and M.A. Mark. 2000a. Leadership skills: conclusions and future directions. Leadership Quarterly. 11: 155-170.

Mumford, M.D., S.J., Zaccaro, J.F., Johnson, D., Maris, J.A., Gilbert, and V.K. Threlfall. 2000b. Patterns of leader characteristics: implications for performance and development. Leadership Quarterly. 11: 115-133.

Nadin, S., and C. Cassell, 2007. New Deal for Old? International Small Business Journal, 25: 417-443.

O'Connell, C. and Mills, A.J. 2003. Making sense of bad news: the media, sensemaking and organizational crisis, Canadian Journal of Communication, 28: 323-39. 
O'Reilly, C.A., D.F., Cladwell, J.A., Chatman, M., Lapiz, and W. Self, 2010. How leadership matters: The effects of leaders' alignment on strategy implementation. The Leadership Quarterly. 21: 104-113.

Osborn, R.N., J.G. Hunt, and L.R. Jauch 2002. Toward a contextual theory of leadership. The Leadership Quarterly, 13: 797-837.

Pearce, C. L., and J.A. Conger, 2007. Shared Leadership Theory. The Leadership Quarterly, 18: 281-288.

Pittinsky, T. L. and S. Simons, 2007. Intergroup Leadership. The Leadership Quarterly, 18: 586-605.

Pomeroy, A. 2005. 'Head of the class', HR Magazine, 50: 54-58

Pye, A. 2005. Leadership and Organizing: Sensemaking in action. Leadership, 1: 3150 .

Raelin, J.A. 2004. Don't bother putting leadership into people. Academy of Management Executive, 18: 131-135.

Raelin, J.A. 2006. Does Action Learning promote Collaborative Leadership? Academy of Management Learning \& Education, 5: 152-16.

Reid, A., L.O. Dahlgren, P. Petocz, and M. Dahlgren, 2008. Identity and engagement for professional engagement, Studies in Higher Education, 33: 729-742.

Sackman, S.A. 1991. Cultural knowledge in organizations: Exploring the collective mind. Sage (Newbury Park, Ca).

Scharmer, C.O. 2001. Self-transcending knowledge: sensing and organising around emerging opportunities. Journal of Knowledge Management, 7: 137-150.

Schutz, A. 1967. Phenomenology of the Social World, Northwestern University Press (Chicago).

Smeby, J-C. 2007. Connecting to professional knowledge. Studies in Higher Education, 32: $207-224$.

Spillane, J. P. 2005. Distributed leadership. The Education Forum, 69: 143-150.

Tamkin, P., Cowling, M. and W. Hunt 2008. People and the Bottom Line, The Work Foundation (London).

Tamkin, P., G. Pearson, W. Hirsh, and S. Constable, 2010. Exceeding Expectations: The Principles of Outstanding Leadership, The Work Foundation (London).

Vaara, E. 2003. Post-acquisition Integration as Sensemaking: Glimpses of Ambiguity, Confusion, Hypocrisy, and Politicization. Journal of Management Studies, 40: 861894. 
Weber, M. 1978. Economy and society: 1. An outline of interpretive sociology, Berkley: University of California Press. In Gordon, R. D. 2002. Conceptualising leadership with respect to its historical-contextual antecedents to power. The Leadership Quarterly, 13: 151-167.

Weick, K.E. 1995. Sensemaking in Organizations, Sage publications (London).

Weick, K. E. 2001. Making Sense of the Organisation, Blackwell (Oxford).

Weick. K.E., and K.H. Roberts, 1993. Collective mind in organizations: Heedful interrelating on flight decks. Administrative Science Quarterly, 38: 357-381.

Weick, K.E., K.M. Sutcliffe, and D. Obstfeld, 2005. "Organizing and the Process of Sensemaking". Organization Science, 16: 409-21.

Yin, R.K. 2003. Case Study Research: Design and Method $\left(3^{\text {rd }}\right.$ ed.). Sage publications (Thousand Oaks, CA). 
Table 1. Foci of leadership theory over the decades

Over the last 100 years: Tamkin et al, 2010, p.8

\begin{tabular}{|l|l|l|l|l|l|l|}
\hline $\begin{array}{l}\text { 1910s to } \\
1920 \mathrm{~s}\end{array}$ & $\begin{array}{l}1930 \mathrm{~s} \\
\text { to } \\
1940 \mathrm{~s}\end{array}$ & $\begin{array}{l}1940 \mathrm{~s} \\
\text { to } \\
1960 \mathrm{~s}\end{array}$ & $1960 \mathrm{~s}$ & $1970 \mathrm{~s}$ & $1980 \mathrm{~s}$ & $2000 \mathrm{~s}$ \\
\hline $\begin{array}{l}\text { Scientific } \\
\text { management }\end{array}$ & $\begin{array}{l}\text { Trait } \\
\text { approach }\end{array}$ & $\begin{array}{l}\text { Style } \\
\text { approach }\end{array}$ & $\begin{array}{l}\text { Situational } \\
\text { and } \\
\text { Contingency } \\
\text { theory }\end{array}$ & $\begin{array}{l}\text { Leaders and } \\
\text { Managers }\end{array}$ & $\begin{array}{l}\text { Transactional, } \\
\text { Charismatic and } \\
\text { Transformational } \\
\text { leadership }\end{array}$ & $\begin{array}{l}\text { Distributed and } \\
\text { Authentic leadership }\end{array}$
\end{tabular}

And since the 1990s: Hunt, 2005

\begin{tabular}{|l|l|}
\hline $1990 \mathrm{~s}$ & $2000-2006$ \\
\hline $\begin{array}{l}\text { Transformational and Charismatic } \\
\text { leadership }\end{array}$ & $\begin{array}{l}\text { Leadership skills, Leaders, Followers and Values, Emotions and } \\
\text { Leadership, Leading for Innovation, Political Leadership } \\
\text { Perspectives, Spiritual Leadership, Authentic Leadership, } \\
\text { Leadership, Self and Identity, } \\
\text { Distributive Leadership, } \\
\text { Evil Leadership and Complexity and Dynamic Systems Leadership }\end{array}$ \\
\hline
\end{tabular}


Table 2. Framework of Sensemaking

\begin{tabular}{|l|l|}
\hline \multicolumn{1}{|c|}{$\begin{array}{c}\text { Framework Characteristics of } \\
\text { Sensemaking }\end{array}$} & Interpretation \\
\hline Grounded in Identity Construction & $\begin{array}{l}\text { Our experiences and social contact continually shapes our } \\
\text { identity. }\end{array}$ \\
\hline Retrospective & $\begin{array}{l}\text { Sensemaking is retrospective and a comparative process. } \\
\text { To interpret the present we rely on past events to give } \\
\text { meaning and make sense of a situation. }\end{array}$ \\
\hline Enactive of the environment & $\begin{array}{l}\text { This relates to making sense of an experience within our } \\
\text { environment. Sensemaking may be constrained or } \\
\text { created by the environment. }\end{array}$ \\
\hline Social & $\begin{array}{l}\text { Social interaction is a key part of the sensemaking } \\
\text { process. }\end{array}$ \\
\hline Ongoing & $\begin{array}{l}\text { Sensemaking is constant as we continue to make sense of } \\
\text { what is happening around us. }\end{array}$ \\
\hline Focuses on and by extracted cues & $\begin{array}{l}\text { Focusing on some elements whilst ignoring others in } \\
\text { order to make sense of a situation/ event }\end{array}$ \\
\hline $\begin{array}{l}\text { Driven by plausibility rather than } \\
\text { accuracy }\end{array}$ & $\begin{array}{l}\text { A reliance on the plausibility of the sensemaking rather } \\
\text { than the accuracy of our perceptions. This can result in } \\
\text { different meanings arising from different groups. }\end{array}$ \\
\hline
\end{tabular}

Source: Compiled from Weick 1995; Mills et al., 2010 